\title{
Article \\ Assessment of Allelopathic Potential of Senna garrettiana Leaves and Identification of Potent Phytotoxic Substances
}

\author{
Ramida Krumsri $^{1,2} \mathbb{D}$, Arihiro Iwasaki ${ }^{3} \mathbb{D}$, Kiyotake Suenaga ${ }^{3}\left(\mathbb{D}\right.$ and Hisashi Kato-Noguchi ${ }^{1,2, *(D)}$ \\ 1 Department of Applied Biological Science, Faculty of Agriculture, Kagawa University, Miki 761-0795, Japan; \\ ramidakrumsri@gmail.com \\ 2 The United Graduate School of Agricultural Sciences, Ehime University, Tarumi, Matsuyama 790-8566, Japan \\ 3 Department of Chemistry, Faculty of Science and Technology, Keio University, Yokohama 223-8522, Japan; \\ a.iwasaki@chem.keio.ac.jp (A.I.); suenaga@chem.keio.ac.jp (K.S.) \\ * Correspondence: kato.hisashi@kagawa-u.ac.jp; Tel.: +81-87-891-3086
}

Citation: Krumsri, R.; Iwasaki, A.; Suenaga, K.; Kato-Noguchi, H. Assessment of Allelopathic Potential of Senna garrettiana Leaves and Identification of Potent Phytotoxic Substances. Agronomy 2022, 12, 139 https://doi.org/10.3390/ agronomy12010139

Academic Editor: Vincenzo Tabaglio

Received: 6 December 2021

Accepted: 5 January 2022

Published: 6 January 2022

Publisher's Note: MDPI stays neutral with regard to jurisdictional claims in published maps and institutional affiliations.

Copyright: (C) 2022 by the authors. Licensee MDPI, Basel, Switzerland. This article is an open access article distributed under the terms and conditions of the Creative Commons Attribution (CC BY) license (https:// creativecommons.org/licenses/by/ $4.0 /$ )

\begin{abstract}
Senna garrettiana (Craib) Irwin \& Barneby (Fabaceae) is a medicinal plant known to be rich in biologically active compounds that could be exploited to produce bioherbicides. The present study was conducted to explore the allelopathic potential and phytotoxic substances of S. garrettiana. Extracts of S. garrettiana leaves were found to significantly inhibit the growth of Lepidium sativum L. and Echinochloa crus-galli (L.) P. Beauv. ( $p \leq 0.05)$. The phytotoxic substances were isolated and identified as vanillic acid and ferulic acid by bioassay-directed fractionation and spectral data analysis. The two compounds were shown to significantly inhibit the seed germination, seedling growth, and dry biomass of L. sativum. Based on the concentration required for $50 \%$ growth inhibition (defined as $\mathrm{IC}_{50}$ ), the roots of L. sativum were the most sensitive to the compounds, and the inhibitory effect of ferulic acid $\left(\mathrm{IC}_{50}=0.62 \mathrm{mM}\right)$ was $>1.3$ times more potent than that of vanillic acid $\left(\mathrm{IC}_{50}=0.82 \mathrm{mM}\right)$. In addition, a mixture of the two compounds $(0.3 \mathrm{mM})$ resulted in synergistic inhibitory activity against the L. sativum roots compared with the individual compounds. These results suggest that the extracts of $S$. garrettiana leaves and their phytotoxic compounds have potential as candidate natural herbicides.
\end{abstract}

Keywords: phytotoxic activity; phenolic compounds; bioherbicide; sustainable agriculture

\section{Introduction}

Allelopathy refers to plants that directly or indirectly release secondary metabolites (called allelochemicals) into the environment [1-3]. These allelochemicals affect the physiological and biochemical processes of neighboring plants and even their plant species to produce an autotoxic effect [4-6]. Allopathic activity has been reported in a large number of Senna species. For example, an extract of the aerial parts of Senna obtusifolia (L.) Irwin \& Barneby inhibited the seed germination and growth of Lactuca sativa L. and Allium cepa L. [7]. An extract of $S$. occidentalis reduced the growth of Handroanthus chrysotrichus (Mart. Ex DC.) Mattos and Tabebuia roseo-alba (Ridl.) Sandwith with increased contents of hydrogen peroxide and malondialdehyde in the radicles and leaves. The phytotoxic compounds contained in Senna occidentalis (L.) include alkaloids, coumarins, phenols, saponins, free steroids, and tannins [8]. Some phytochemical features that make the extract a potential natural herbicide include its similar mechanisms of action to synthetic herbicides; total or partial solubility for easy application without surfactants; and chemical structures with high oxygen and nitrogen contents that are environmentally friendly, reduce the environmental half-life, and prevent accumulation in the soil [9]. Therefore, researchers have focused on utilizing allelopathic species and their allelopathic compounds as natural herbicides [10-12]. The crude extracts or plant residues can be directly applied as bioherbicides, while the compounds isolated from the allelopathic plants can be used as templates for developing natural herbicides [13-15]. However, differences in the allelopathic compound composition, 
concentration, and allopathic properties of the plant species vary significantly with effects unique to the target plant species [16]. Therefore, screening new allelopathic species and identifying active compounds with a high allelopathic activity could augment current weed control approaches. Thus, members of the genus Senna are potentially valuable sources of bioactive compounds for alternative weed management strategies.

The genus Senna (Fabaceae family) includes approximately 300 species with a tropical distribution, most of which are widely found in the Americas, Africa, Australia, and Asia [17]. This genus contains annuals, subshrubs, and woody and erect plants [7]. The pharmacologically bioactive compounds in various Senna spp. have been investigated. Studies have revealed that Senna produces more than 120 structurally diverse phytochemicals [18]. The crude extracts, fractions, and compounds obtained from Senna spp. have been shown to possess antimalarial, antidiabetic, antimicrobial, antioxidant, anti-inflammatory, analgesic, antitumor, antinociceptive, and anticancer properties [19]. Notably, several members of this genus also have allelopathic potential and contain potent phytotoxic substances $[7,20]$.

Senna garrettiana (Craib) Irwin \& Barneby is a Thai medicinal plant in the Fabaceae family, known locally as "Samae-sarn". This plant is widely distributed in all regions of Thailand and is commonly used as an ornamental and food tree [21]. The trunk height is approximately $10 \mathrm{~m}$ and has thick dark brown or black bark. The leaves are elongated and oval with a spear-like tip, and its flowers are yellow or golden in color. The skin of the pods is smooth and completely hairless [22] (Figure 1). The heartwood of S. garrettiana has been used traditionally to attenuate muscle pain, nourish the blood, and promote menstrual discharge [23]. An extract of S. garrettiana has been shown to have anti-hyaluronidase and anti-elastase activities due to the presence of betulinic acid [24]. Many compounds isolated from $S$. garrettiana, such as cassialoin and chrysophanol-9-anthrone, possess anticancer properties [25]. In addition, the bioactive compounds in this species such as piceatannol (trans-3,3',4,5'-tetrahydroxystilbene), a derivative of phenolic stilbene, exhibit antioxidant, antipyretic, and anti-inflammatory activities [23,26,27]. Researchers have found that pharmacologically bioactive compounds can interact with multiple targets. For example, rutin (3,3', $4^{\prime}, 5,7$-pentahydroxyflavone-3-rhamnoglucoside), found in the Senna species [28], has a number of pharmacological activities [29] and possesses the ability to alter the specific expression pattern of the short-root and HD-zip III transcription factor gene family and cause morpho-physiological alterations in Sorghum bicolor (L.) Moench roots [30]. Based on its value as a traditional medicine and its secondary substances, it is possible that $S$. garrettiana has significant allelopathic activity with high phytochemical contents. Moreover, it has been observed that the growth and abundance of plant species under the S. garrettiana canopy is scant (Figure 1A). One possible reason for this inhibition or suppression could be the allelopathic potential of this species. Although the biological activity of this species has been extensively studied, the allopathic activity of $S$. garrettiana has not been reported. Consequently, the aims of the current research were (i) to assess the allelopathic potential of S. garrettiana leaf extracts against the seedling growth of L. sativum and E. crus-galli, (ii) to isolate and identify the major phytotoxic compounds, and (iii) to identify the biological activity of the candidate phytotoxic compounds against test plant species. 


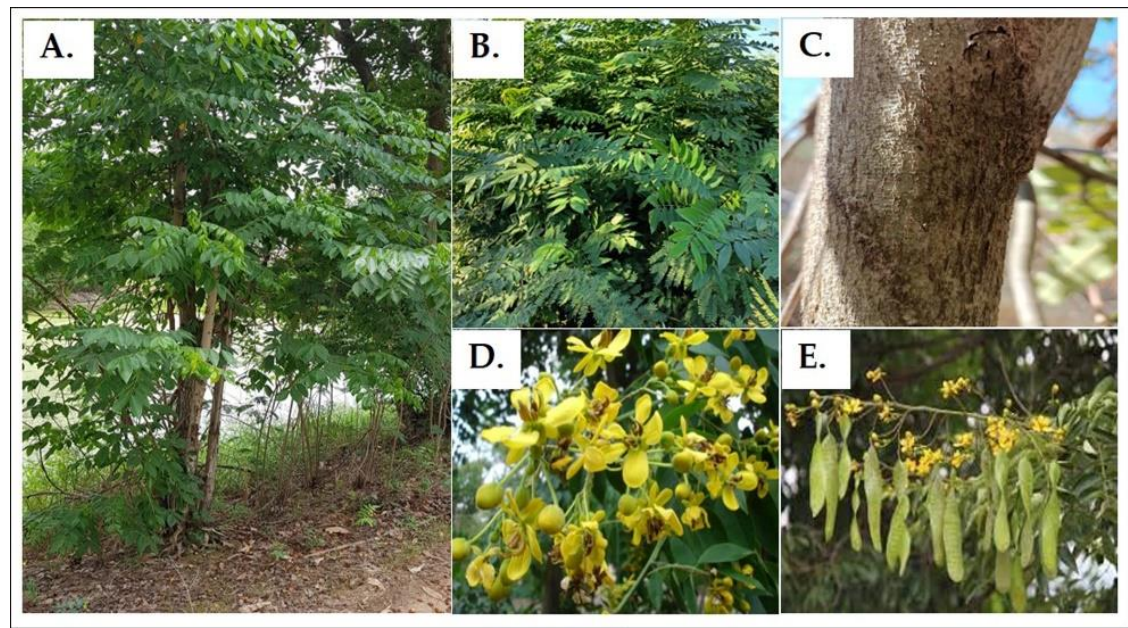

Figure 1. S. garrettiana in the natural ecosystem: (A) the suppression zone of $S$. garrettiana that reduces the growth of other plant species under the canopy, (B) leaves, (C) trunks, (D) flowers, and (E) pods of S. garrettiana.

\section{Materials and Methods}

\subsection{Plant Material}

Leaves of $S$. garrettiana were obtained from Phitsanulok Province, Thailand $\left(16^{\circ} 49^{\prime} \mathrm{N}\right.$ and $100^{\circ} 16^{\prime} \mathrm{E}$ ). The material was rinsed in tap water to remove impurities and then air-dried in the shade. The material was pulverized, sieved using a $2 \mathrm{~mm}$ mesh, and refrigerated at $4{ }^{\circ} \mathrm{C}$ until it was extracted. L. sativum and E. crus-galli were selected as test plant species to evaluate the biological activity of $S$. garrettiana leaf extracts. E. crus-galli seeds were used because of their worldwide distribution, whereas L. sativum seeds were used because of their well-known growth behavior [31,32].

\subsection{Extraction and Bioassay Procedure}

Dried leaves of S. garrettiana (100 g) were immersed in $500 \mathrm{~mL}$ of methanol and distilled water $(70: 30, v / v)$ and kept in the dark for $48 \mathrm{~h}$. The solution was filtered through filter paper (Whatman No. 2, Tokyo, Japan). The residue was re-immersed in an equal volume of methanol for $24 \mathrm{~h}$ and the solution was filtered. The two filtrates were mixed and concentrated at $40{ }^{\circ} \mathrm{C}$ in a rotary evaporator (Yamato Scientific Co., Ltd., Tokyo, Japan). The dry filtrate was dissolved in methanol and six different concentrations were prepared. Aliquots of the extracts $(600 \mu \mathrm{L})$ and control (methanol without plant extract) were added to filter paper (Whatman No. 2) in $28 \mathrm{~mm}$ Petri dishes. After applying the extracts, the solvent was allowed to dry and then $600 \mu \mathrm{L}$ of an aqueous solution $(0.05 \%$ Tween 20 in distilled water) was added. Ten L. sativum seeds or ten E. crus-galli seedlings (germinated in the dark at $25^{\circ} \mathrm{C}$ for $36 \mathrm{~h}$ ) were arranged on the Petri dishes. The seeds or seedlings were incubated in a growth cabinet in the dark at $25^{\circ} \mathrm{C}$. The shoot and root lengths of the test plant seedlings were measured after $48 \mathrm{~h}$ of incubation. The experiments were conducted following a completely randomized design with three replications. The percentage of inhibition was estimated using the following equation: \% seedling growth $=$ (the length of the treated seedling/the length of the control seedling) $\times 100$.

\subsection{Separation of the Active Fraction of the Aqueous Methanol Extract from the S. garrettiana Leaves}

A crude extract of $S$. garrettiana leaves was prepared according to the extraction procedure described in Section 2.2. The crude extract was re-dissolved in distilled water and the $\mathrm{pH}$ was adjusted to 7 using $1 \mathrm{M}$ phosphate buffer. The residue solution was partitioned against an equal volume of ethyl acetate (three times) and divided into the ethyl acetate and aqueous fractions. The ethyl acetate fraction was dried and filtered over 
anhydrous $\mathrm{Na}_{2} \mathrm{SO}_{4}$. The solvent from each fraction was dried and re-dissolved in the original solvent. The L. sativum and E. crus-galli seedlings were used as test plants to assess the biological activity of the $S$. garrettiana leaf extracts at different concentrations. The incubation conditions, experimental design, data collection, and calculations were the same as for the extract bioassay.

\subsection{Isolation and Identification of the Phytotoxic Substances in the S. garrettiana Leaves}

The ethyl acetate fraction separated from the $S$. garrettiana leaf extracts was chromatographed on a silica gel column, a Sephadex LH-20 column, and a reverse-phase $\mathrm{C}_{18}$ SPE cartridge, as described by Krumsri et al. [33], with some modifications. The L. sativum bioassay was used to assess the biological activity of all the fractions collected during the isolation steps. The fraction eluted from the silica gel column (silica gel 60, spherical, 70-230 mesh: Nacalai Tesque, Kyoto, Japan) with 60\% ethyl acetate in $n$-hexane exhibited the highest inhibitory activity. This fraction was separated using a Sephadex LH-20 column (GE Healthcare Bio-Science AB, Uppsala, Sweden). The fraction eluted with $80 \%$ aqueous methanol was active. The active fraction was then subjected to the reverse-phase $C_{18}$ solid phase extraction (SPE) cartridges (YMC Dispo SPE, YMC Ltd., Kyoto, Japan). The active fraction ( $20 \%$ aqueous methanol) was finally purified on high-performance liquid chromatography (HPLC; Shimadzu Corporation, Kyoto, Japan) with a reverse-phase HPLC column $\left(250 \times 4.6 \mathrm{~mm}\right.$ I.D., $5 \mu \mathrm{m}$, Inertsil ${ }^{\circledR}$ ODS-3; GL Science Inc., Tokyo, Japan). The substances were eluted using an isocratic system of methanol: water $(20: 80,(v / v))$ at a flow rate of $0.8 \mathrm{~mL} \mathrm{~min}^{-1}$ and detected at $220 \mathrm{~nm}$.

The inhibitory activity was found in peak fractions at retention times of 70-100 min (substance 1) and 30-50 min (substance 2). The substances were characterized by atmospheric pressure chemical ionization-mass spectrometry (APCI-MS), electrospray ionizationmass spectrometry (ESI-MS), and ${ }^{1} \mathrm{H}$-nuclear magnetic resonance (NMR) spectra $(400 \mathrm{MHz}$, $\left.\mathrm{CD}_{3} \mathrm{OD}\right)$.

\subsection{Bioassay of the Phytotoxic Substances from the S. garrettiana Leaves}

Individual substances were prepared at concentrations of $0.03,0.1,0.3,1,3$, and $10 \mathrm{mM}$, and a mixture of the two substances was prepared to $0.3 \mathrm{mM}$ (ratio 1:1). Their biological activity L. sativum was examined using the above procedure. After a $48 \mathrm{~h}$ incubation, the seed germination, shoot length, root length, and dry biomass were measured and calculated in the same way as for the extract bioassay.

\subsection{Statistical Analysis}

Analysis of variance (ANOVA) and Tukey's honestly significant difference (HSD) test was used to analyze the effects between treatments by the SPSS version 25.0 software (IBM Corp., Chicago, IL, USA). The significance of the F-values was tested at a $p$-value $\leq 0.05$. The $\mathrm{IC}_{50}$ values of the test plant species were determined using GraphPad Prism 6.0 (GraphPad Software, Inc., La Jolla, CA, USA).

\section{Results and Discussion}

\subsection{Biological Activity of the the Aqueous Methanol Extracts of S. garrettiana Leaf}

S. garrettiana leaf extracts had a marked effect on the length of the L. sativum and E. crus-galli seedlings ( $p \leq 0.05$, Table 1 ) in a dose- and species-dependent manner. The growth of the seedlings of both species was significantly inhibited compared with the control seedlings at extract concentrations $\geq 3 \mathrm{mg}$ dry weight (DW) equivalent extract $\mathrm{mL}^{-1}$. The extract concentration of $10 \mathrm{mg}$ DW equivalent extract $\mathrm{mL}^{-1}$ inhibited the length of the L. satioum and E. crus-galli shoots by 39.8 and $31.0 \%$, respectively, compared with the control, whereas the root length was inhibited by 36.6 and $39.0 \%$, respectively, compared with the control. Moreover, the results of the ANOVA showed that the extract concentration and test plant species were significant factors in the growth rates of the shoots $(\mathrm{F}=53.6$, $p<0.001)$ and roots $(\mathrm{F}=85.5, p<0.001)$. 
Table 1. Growth inhibitory effects of the aqueous methanol extracts of S. garrettiana leaf against the L. sativum and E. crus-galli seedlings at different concentrations after $48 \mathrm{~h}$ of treatment.

\begin{tabular}{|c|c|c|c|}
\hline $\begin{array}{l}\text { Test Plant } \\
\text { Species }\end{array}$ & $\begin{array}{c}\text { Leaf Extract Concentration } \\
\text { (mg DW Equivalent Extract } \mathrm{mL}^{-1} \text { ) }\end{array}$ & $\begin{array}{l}\text { Shoot Length } \\
(\mathrm{mm})\end{array}$ & $\begin{array}{l}\text { Root Length } \\
(\mathrm{mm})\end{array}$ \\
\hline \multirow{9}{*}{ L. sativum } & Control & $8.47 \pm 0.27^{\mathrm{a}}$ & $17.50 \pm 0.97^{\mathrm{a}}$ \\
\hline & 1 & $8.12 \pm 0.30^{a}$ & $17.27 \pm 0.71^{\mathrm{a}}$ \\
\hline & 3 & $7.24 \pm 0.33^{b}$ & $15.87 \pm 0.57^{\mathrm{a}}$ \\
\hline & 10 & $5.10 \pm 0.22^{c}$ & $11.10 \pm 2.22^{b}$ \\
\hline & 30 & $1.08 \pm 0.14^{\mathrm{d}}$ & $2.22 \pm 0.13^{c}$ \\
\hline & 100 & $1.25 \pm 0.09^{\mathrm{e}}$ & $1.07 \pm 0.04^{\mathrm{cd}}$ \\
\hline & 300 & $0.00 \pm 0.00^{f}$ & $0.00 \pm 0.00^{\mathrm{d}}$ \\
\hline & F & 3.05 & 24.58 \\
\hline & $p$-value & $<0.001$ & $<0.001$ \\
\hline \multirow{9}{*}{ E. crus-galli } & Control & $19.73 \pm 1.02^{\mathrm{a}}$ & $15.43 \pm 0.99^{a}$ \\
\hline & 1 & $18.60 \pm 0.52^{\mathrm{a}}$ & $15.33 \pm 0.46^{\mathrm{a}}$ \\
\hline & 3 & $15.55 \pm 0.66^{b}$ & $12.13 \pm 0.55^{b}$ \\
\hline & 10 & $13.61 \pm 0.58^{b}$ & $9.27 \pm 0.57^{c}$ \\
\hline & 30 & $10.35 \pm 0.69^{c}$ & $4.48 \pm 0.52^{\mathrm{d}}$ \\
\hline & 100 & $3.95 \pm 0.18^{d}$ & $1.35 \pm 0.12^{\mathrm{e}}$ \\
\hline & 300 & $0.00 \pm 0.00^{\mathrm{e}}$ & $0.00 \pm 0.00^{\mathrm{e}}$ \\
\hline & F & 154.86 & 1.79 \\
\hline & $p$-value & $<0.001$ & $<0.001$ \\
\hline Interaction species & $\mathrm{F}$ & 53.85 & 85.52 \\
\hline$\times$ treatment & $p$-value & $<0.001$ & $<0.001$ \\
\hline
\end{tabular}

Experimental data are the mean $( \pm$ S.D.) of three replicates $(n=30)$; different superscript letters in each row-column indicate a statistically significant difference between treatments (Tukey's HSD, at the 0.05 probability level).

Such different degrees of inhibition of the test plants may be related to the bioactive compounds exhibiting increased inhibitory effects on physiological processes as the concentration increased. Our results are consistent with previous research, which reported that Senna species have inhibitory activity, such as extracts of S. obtusifolia and S. occidentalis causing the inhibition of the seed germination and growth of plant species [7,8]. Moreover, the unequal susceptibility of the tested species to the extracts could be due to inherent differences in the biochemicals involved in the process [34]. The species specificity of phytotoxic substances has also been demonstrated for other allelopathic plant species [35-37]. In general, plant extracts comprise a mixture of various bioactive and inactive compounds with different polarities [38]. Therefore, further studies were carried out on leaf extracts to separate the active fractions using different organic solvents.

\subsection{Separation of the Active Fraction in the S. garrettiana Leaf Extracts}

S. garrettiana leaf extracts were partitioned with different liquid organic solvents. The partitioning results revealed that the aqueous and ethyl acetate fractions had significant inhibitory effects on the L. sativum and E. crus-galli seedlings compared with the control $(p \leq 0.05$, Figure $2 \mathrm{~A}, \mathrm{~B})$. The $\mathrm{IC}_{50}$ values of the test plants showed that the inhibition by the ethyl acetate fraction was greater than that by the aqueous fraction, and L. sativum was the most sensitive to both fractions (Table 2).

These results showed that the phytotoxic substances from the S. garrettiana leaf extracts had the highest inhibitory activity in the ethyl acetate fraction. Several studies have reported the ability of the growth inhibitory activity of ethyl acetate fractions. Silva et al. [39] showed that the ethyl acetate fraction of Hydrocotyle bonariensis Lam. inhibits the growth of L. sativum, Solanum lycopersicum L., Allium cepa L., and Triticum aestivum L. seedlings and has high levels of phenolic compounds. Pereira et al. [40] found that the ethyl acetate fraction of Pancratium maritimum L. inhibits the tested plants due to the presence of tannins, flavanone, steroids, and saponins. Previous research indicates that active fractions from allelopathic plant extracts contain bioactive compounds. Moreover, Blum [41] and 
Mirmostafaee et al. [42] reported that two or more compounds usually act together and have synergistic or antagonistic effects on plant growth, depending on the combination used. Consequently, it is crucial to determine which compounds play a significant role in phytotoxicity and hence have potential use in weed control. The potent phytotoxic substances in the S. garrettiana leaf extracts were further isolated using the bioassay-guided fractionation method.

(A) L. sativum

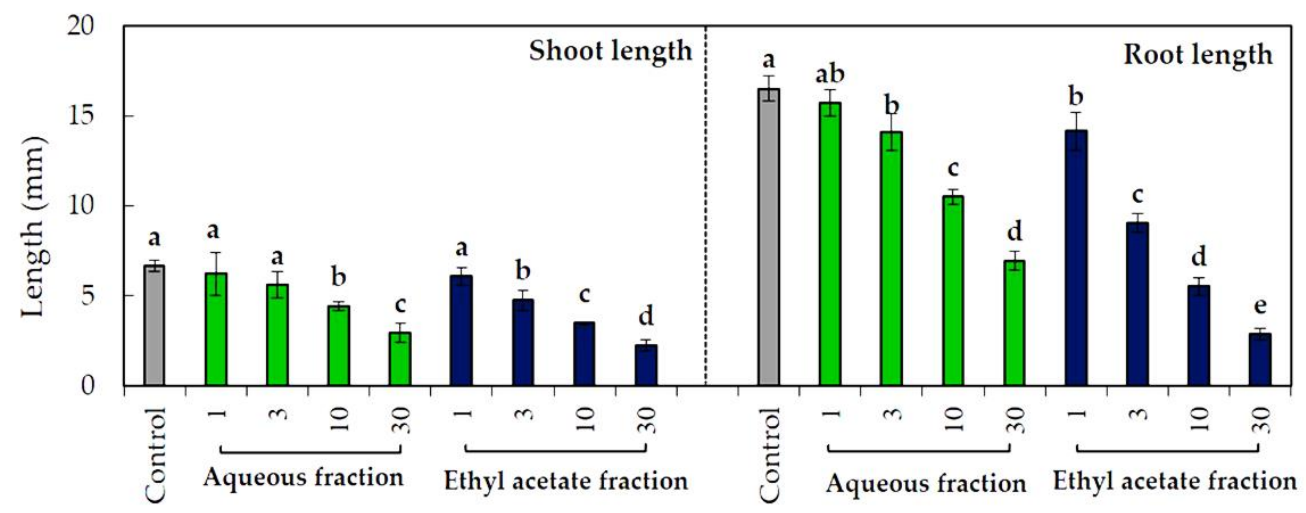

(B) E. crus-galli

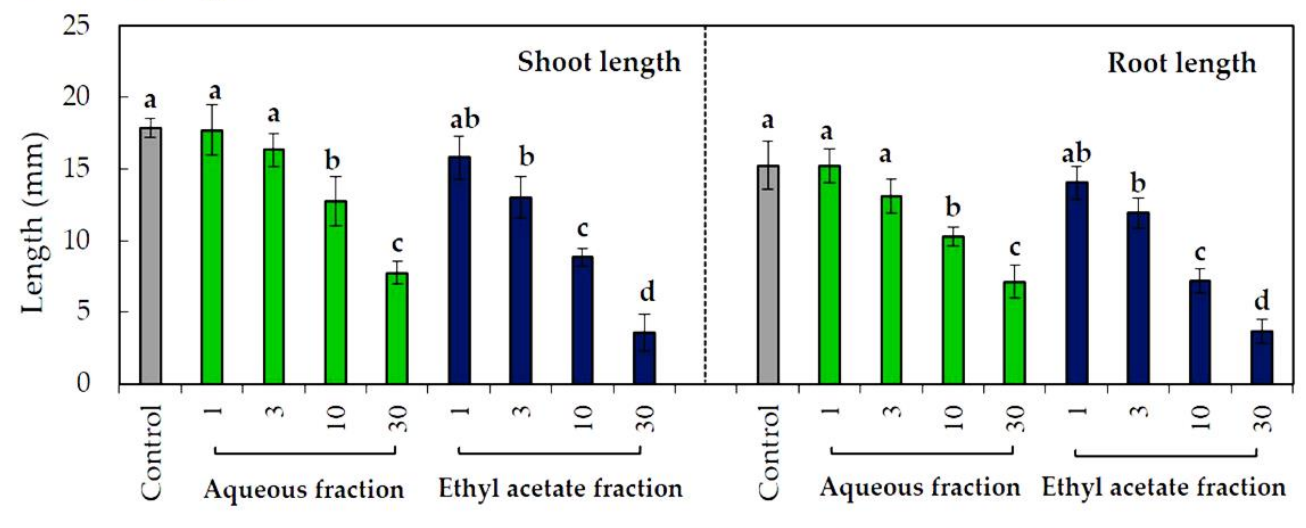

Concentration: mg DW equivalent extract $/ \mathrm{mL}$

Figure 2. Growth inhibitory effect of the aqueous and ethyl acetate fractions separated from the S. garrettiana leaf extracts against the growth of (A) L. sativum seedlings and (B) E. crus-galli seedlings. Values are the mean $( \pm$ S.D. $)$ of three replicates $(n=30)$; different letters on each bar indicate a statistically significant difference between treatments (Tukey's HSD, at the 0.05 probability level).

Table 2. The concentration required for $50 \%$ growth inhibition $\left(\mathrm{IC}_{50}\right)$ of the shoot and root growth of test plant species by the aqueous and ethyl acetate fractions separated from S. garrettiana leaf extracts.

\begin{tabular}{ccccc}
\hline \multirow{2}{*}{ Fraction } & \multicolumn{4}{c}{$\begin{array}{c}\text { IC }_{\mathbf{5 0}} \text { Value } \\
\left(\mathbf{m g ~ D W} \text { Equivalent Extract } \mathbf{~ m L}^{-\mathbf{1}}\right)\end{array}$} \\
\hline & \multicolumn{2}{c}{ L. sativum } & \multicolumn{2}{c}{ E. crus-galli } \\
\hline & Shoot & Root & Shoot & Root \\
Aqueous & 21.93 & 18.12 & 26.23 & 22.40 \\
Ethyl acetate & 16.13 & 13.32 & 19.87 & 18.02 \\
\hline
\end{tabular}




\subsection{Isolation and Identification of the Phytotoxic Substances in the S. garrettiana Leaf Extracts}

The ethyl acetate fraction from the $S$. garrettiana leaf extracts was fractioned through silica gel, Sephadex LH-20, and reverse-phase $\mathrm{C}_{18}$ SPE cartridges. Reverse-phase HPLC was used to purify the active substances and two active substances were detected.

Active substance 1 has the molecular formula $\mathrm{C}_{8} \mathrm{H}_{8} \mathrm{O}_{4}$, as established using APCI-MS at $m / z$ 167.0339 $[\mathrm{M}+\mathrm{H}]^{-}$(calcd. For $\mathrm{C}_{8} \mathrm{H}_{7} \mathrm{O}_{4}, 167.0344$ ). The spectrum data of ${ }^{1} \mathrm{H}$ NMR $\left(400 \mathrm{MHz}, \mathrm{CD}_{3} \mathrm{OD}\right)$ presented $\delta_{\mathrm{H}}: 7.56(\mathrm{~d}, J=1.3 \mathrm{~Hz}, 1 \mathrm{H}, \mathrm{H}-3), 7.55(\mathrm{dd}, J=8.5 \mathrm{~Hz}, 1 \mathrm{H}, \mathrm{H}-7)$, $6.84(\mathrm{~d}, J=8.5 \mathrm{~Hz} 1 \mathrm{H}, \mathrm{H}-6), 3.89(\mathrm{~s}, 3 \mathrm{H}, \mathrm{H}-8)$. These spectroscopic data were compared with previous literature and the substance was identified as 4-hydroxy-3-methoxybenzoic acid [43], which is known as vanillic acid (Figure 3A).

(A)
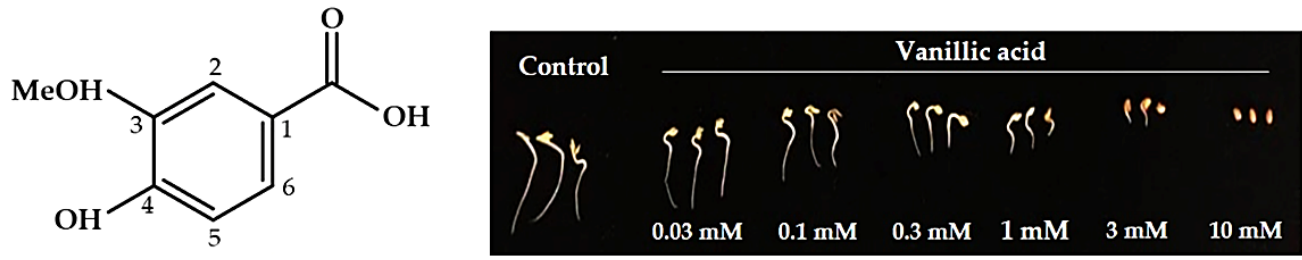

Vanillic acid

(B)

(C)
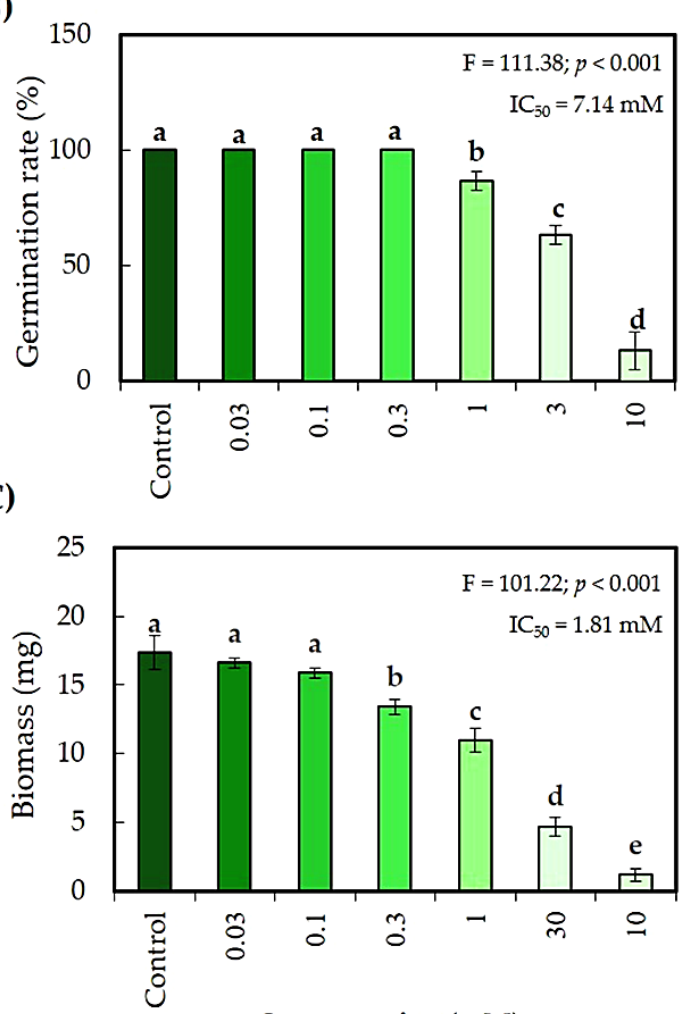

(D)

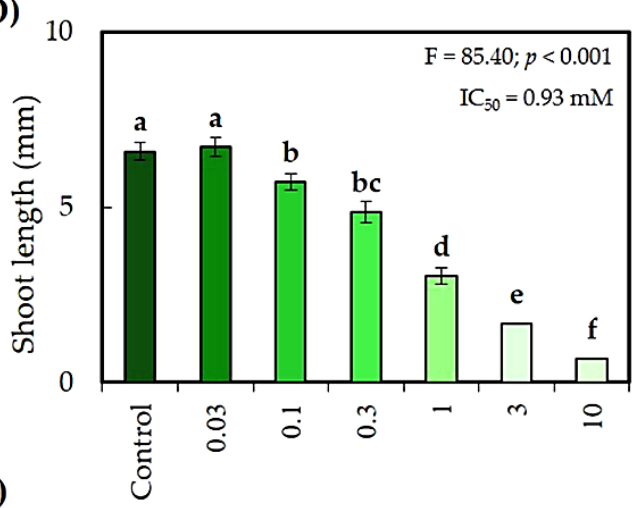

(E)



Figure 3. Growth inhibitory effects on Lepidium sativum exposed to vanillic acid isolated from the S. garrettiana leaf extracts. (A) L. sativum seedlings after $48 \mathrm{~h}$ of treatment, (B) seed germination, (C) dry biomass, (D) shoot length, and (E) root length. Values are the mean ( \pm S.D.) of three replicates $(n=30)$; different letters on each bar indicate a statistically significant difference between treatments (Tukey's HSD, at the 0.05 probability level).

Active substance 2 has the molecular formula $\mathrm{C}_{10} \mathrm{H}_{10} \mathrm{O}_{4}$, as established using ESI-MS at $m / z 195.0660[\mathrm{M}+\mathrm{H}]^{+}$(calcd. for $\mathrm{C}_{10} \mathrm{H}_{11} \mathrm{O}_{4}, 195.0657$ ). The spectrum data of ${ }^{1} \mathrm{H}$ NMR $\left(400 \mathrm{MHz}, \mathrm{CD}_{3} \mathrm{OD}\right)$ presented $\delta_{\mathrm{H}}: 7.59(\mathrm{~d}, J=16.1 \mathrm{~Hz}, 1 \mathrm{H}, \mathrm{H}-3), 7.18(\mathrm{~d}, J=1.8 \mathrm{~Hz}, 1 \mathrm{H}$, H-9), $7.07(\mathrm{dd}, J=8.2,1.8 \mathrm{~Hz}, 1 \mathrm{H}, \mathrm{H}-5), 6.81(\mathrm{~d}, J=8.2 \mathrm{~Hz}, 1 \mathrm{H}, \mathrm{H}-6), 6.32(\mathrm{~d}, J=16.1 \mathrm{~Hz}$, $1 \mathrm{H}, \mathrm{H}-2), 3.90(\mathrm{~s}, 3 \mathrm{H}, \mathrm{H}-10)$. Comparison of these spectral analysis data with published 
data identified the substance as 3-methoxy-4-hydroxycinnamic acid [43]. This compound is commonly known as ferulic acid (Figure $4 \mathrm{~A}$ ).

(A)

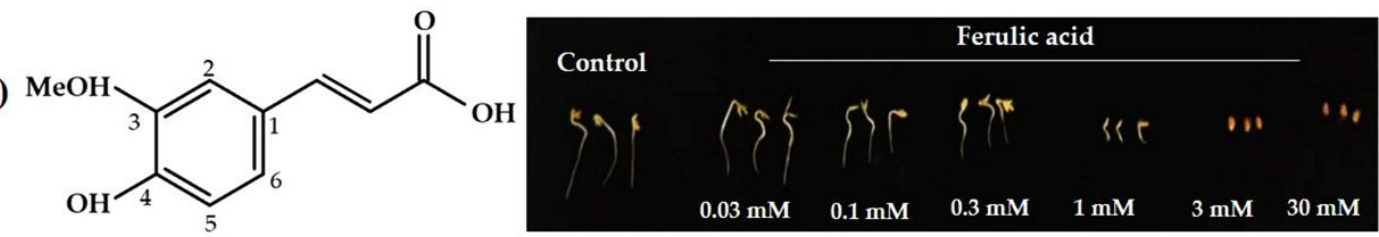

Ferulic acid

(B)

(C)
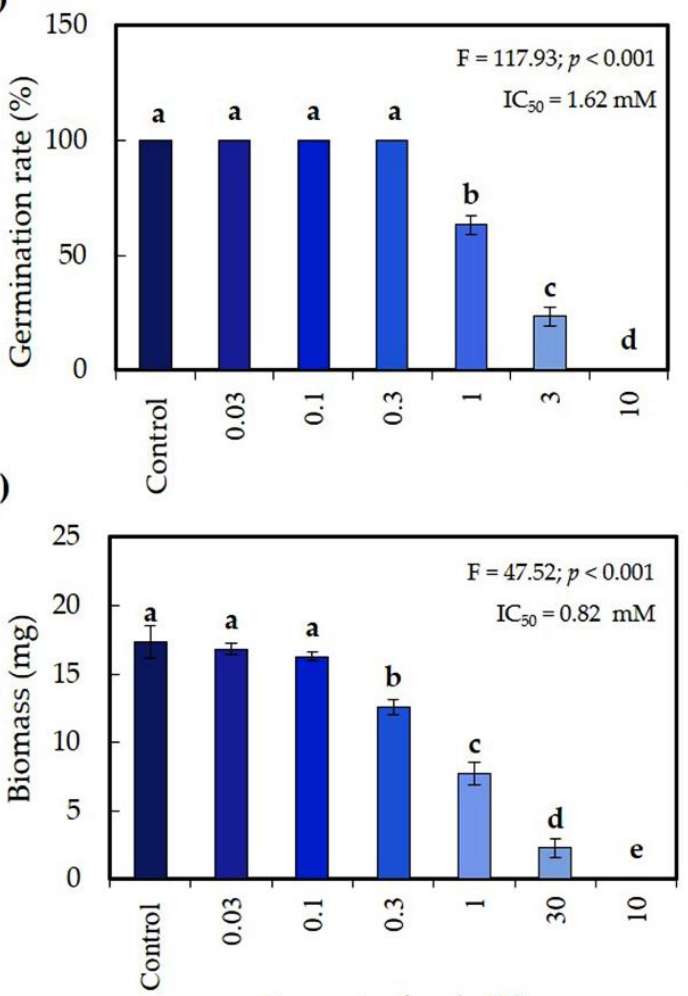

(D)

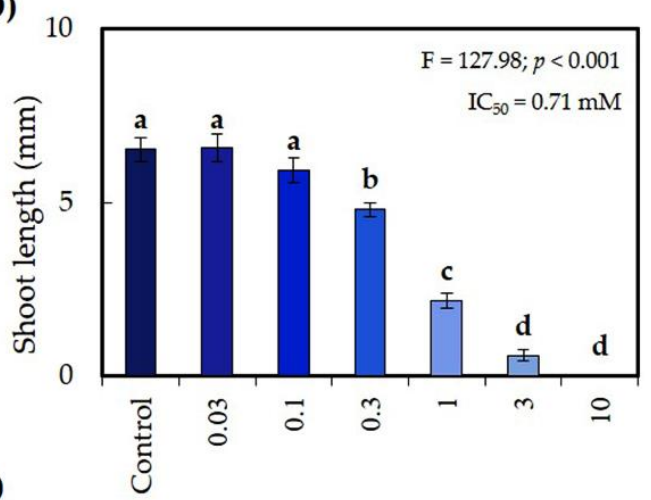

(E)

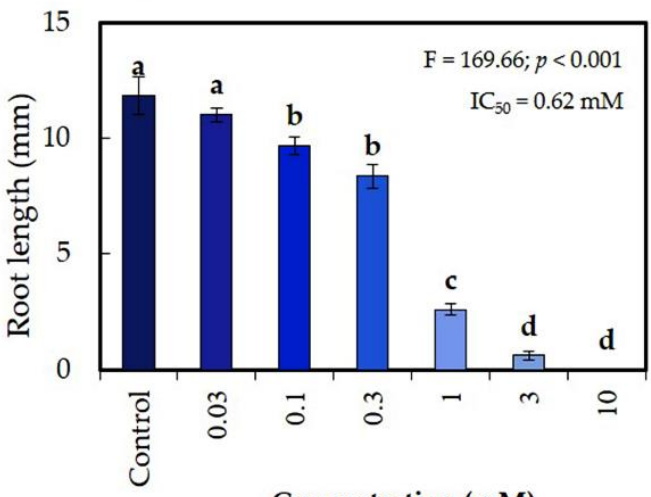

Figure 4. Growth inhibitory effects on Lepidium sativum exposed to ferulic acid isolated from the S. garrettiana leaf extracts. (A) L. sativum seedlings after $48 \mathrm{~h}$ of treatment, (B) seed germination, (C) dry biomass, (D) shoot length, and (E) root length. Values are the mean ( \pm S.D.) of three replicates $(\mathrm{n}=30)$; different letters on each bar indicate a statistically significant difference between treatments (Tukey's HSD, at the 0.05 probability level).

Vanillic acid and ferulic acid are phenolic compounds. Vanillic acid is a benzoic acid derivative [44], while ferulic acid is a cinnamic acid derivative [45]. Both compounds have been detected widely in plant species such as Saccharum officinarum L. [46], Lantana camara L. [47], and Triticum aestivum L. [48]. They are considered potential anti-inflammatory compounds [49,50], with microbial activity [51] and antioxidant activities [52,53]. Our findings suggest that the leaves of $S$. garrettiana are a source of vanillic acid and ferulic acid, which have phytotoxic effects on plant growth.

\subsection{Biological Activity of the Compounds Isolated from the S. garrettiana Leaf Extract against L. satioum}

The phytotoxic activity of vanillic acid and ferulic acid was determined against L. sativum. The inhibitory potential of the two compounds significantly affected the seed germination, seedling growth, and dry biomass of L. sativum ( $p \leq 0.05$, Figures 3 and 4$)$. 
The degree of inhibition of the L. sativum growth parameters by both compounds increased with increased concentration. The seed germination, shoot length, root length, and dry biomass of L. sativum were inhibited by $23.4,53.6,57.0$, and $37.0 \%$, respectively, in response to $1 \mathrm{mM}$ of vanillic acid. Based on the $\mathrm{IC}_{50}$ values, the order of inhibition efficiency was root length $(0.82 \mathrm{mM})>$ shoot length $(0.93 \mathrm{mM})>$ dry biomass $(1.81 \mathrm{mM})>$ germination (7.14 mM) (Figure 2). In contrast, $1 \mathrm{mM}$ of ferulic acid inhibited the seed germination, shoot length, root length, and dry biomass by $26.7,76.7,78.2$, and $44.3 \%$, respectively. The $\mathrm{IC}_{50}$ values showed that the degree of inhibition of the growth parameters was root length $(0.62 \mathrm{mM})>$ shoot length $(0.71 \mathrm{mM})>$ dry biomass $(0.82 \mathrm{mM})>$ germination $(1.62 \mathrm{mM})$ (Figure 3). Furthermore, a $0.3 \mathrm{mM}$ mixture of vanillic acid and ferulic acid had synergistic effects against L. sativum (Figure 5). The inhibitory effect on the L. sativum roots by the mixture of the compounds was 1.15 and 1.41 times more than vanillic acid and ferulic acid alone, respectively. No significant inhibitory effect was observed on the seed germination or shoot length.

(A)

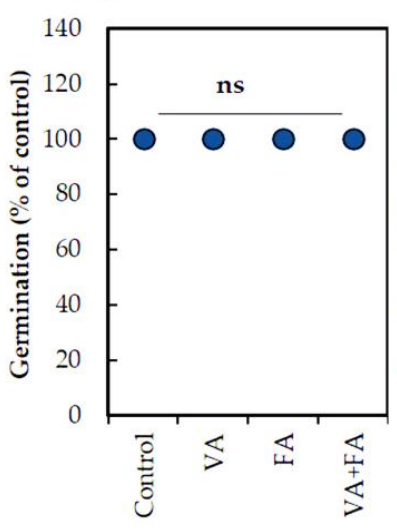

(B)

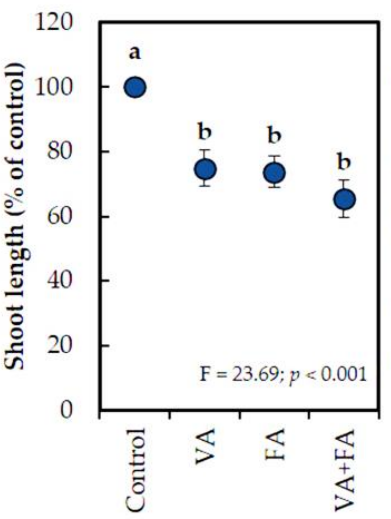

(C)

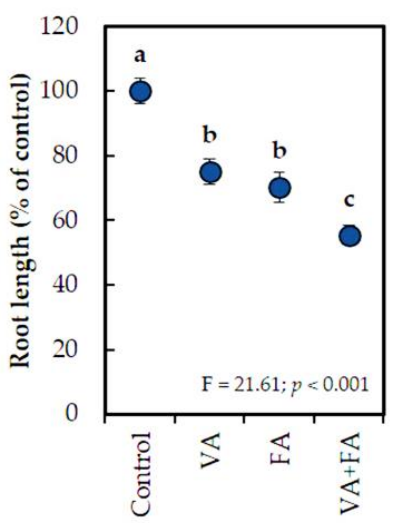

(D)

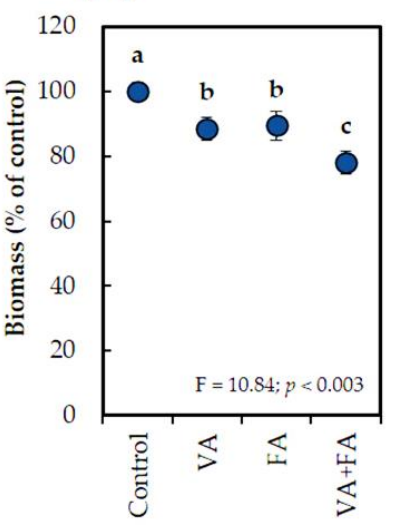

Figure 5. Growth inhibitory effects of a mixture of vanillic acid (VA) and ferulic acid (FA) at a concentration of $0.3 \mathrm{mM}$ on (A) seed germination, (B) shoot length, (C) root length, and (D) dry biomass of L. sativum. Values are the mean ( \pm S.D.) of three replicates $(n=30)$; different letters on each bar indicate a statistically significant difference between treatments (Tukey's HSD, at the 0.05 probability level).

Plant seed germination and seedling growth (shoot length, root length, and plant biomass) are critical steps in the growth and development of plant species, showing the significance of high allelopathic activity [54,55]. In this study, vanillic acid and ferulic acid appeared to alter seed germination and seedling growth and significantly reduced the dry biomass of L. sativum. These results support early studies reporting that both compounds possess potent phytotoxicity [56,57]. Moreover, our results showed that the percentage of $L$. sativum seed germination was the least affected parameter and that the root length of L. sativum was the most inhibited by both compounds. Therefore, the results indicated that these compounds had higher potential for inhibiting seedling growth than seed germination in L. sativum. The greater sensitivity of root growth to compounds is because radicles have more permeable tissue than other organs [58]. Thus, roots are less protected by the cuticle than shoots, leading to a higher accumulation of phytotoxic compounds in root tissues. Both compounds possess phytotoxic properties that cause excessive reactive oxygen species (ROS) and oxidative stress in vitro [59,60], which may be one reason for their growth inhibitory activity. The accumulation of ROS and changes in the antioxidant system of plants lead to membrane lipid peroxidation and the impaired structure and function of the entire cell membrane, thereby inhibiting plant growth [61-63]. Talukdar [64] also reported that an aqueous extract of Lantana camara L. inhibits the root development and growth of Lathyrus sativus L. due to increased lipid peroxidation and membrane damage. Although both compounds in this study initially appeared to have 
similar activities, the inhibition levels by ferulic acid were higher than those by vanillic acid for all growth parameters, particularly root growth. These findings suggest that both compounds may have a more active analog via the same mechanism or that these structurally related molecules have different modes of action. Both compounds have the same structure, except for the functional group at the C-1 position (Figures $3 \mathrm{~A}$ and $4 \mathrm{~A}$ ). Different compositions and concentrations of phenolic compounds may be responsible for differences in activity, making the mode of action unique [16]. Therefore, we inferred that the functional group at the C-1 position may be key to the phytotoxic activity of phenolic acids. However, we have not studied the phytotoxic effects of either compound on L. satioum seedlings at the molecular level; thus, the effects on cell division and elongation, as well as on growth regulation, must be determined in future studies.

Moreover, the mixture of vanillic acid and ferulic acid $(0.3 \mathrm{mM})$ had greater inhibitory effects than the individual compounds (Figure 5), suggesting synergistic activity that strongly reduced the root growth of L. sativum. This finding agrees with the results of Rial et al. [65] and Tena et al. [66], who found a synergistic effect of allelopathic activity in a mixture of phytotoxic compounds. A higher inhibitory effect of a mixture of compounds compared with the individual compounds suggests that allelopathy is influenced by the type of compound combination used, concentration interactions, and the sensitivity of receptor plant species $[67,68]$. Therefore, the effects of a mixture of these compounds on different indicator plants should be investigated to examine whether they are potential new herbicides.

\section{Conclusions}

Aqueous methanol extracts of $S$. garrettiana leaf exhibited a significant growth inhibitory effect on the test plants at extract concentrations $\geq 3 \mathrm{mg}$ DW equivalent extract $\mathrm{mL}^{-1}$ and increasing the extract concentration increased the inhibition. These results indicate that extracts of $S$. garrettiana leaves might contain potent phytotoxic substances. The bioassay-directed fractionation of the S. garrettiana leaf extracts resulted in the isolation of vanillic acid and ferulic acid. Both compounds tended to have similar effects on the growth of L. sativum, particularly on the root growth. It was also observed that the level of inhibition by ferulic acid against all the growth parameters was greater than that by vanillic acid. In addition, a low concentration of a mixture of vanillic acid and ferulic acid had a synergistic inhibitory effect on the L. sativum roots. Our results indicate that the phytotoxic compounds in the S. garrettiana leaf extracts are potential candidates for developing natural herbicides. Future studies should determine the combined effects of these two compounds on their mode of action at the molecular level in target plants.

Author Contributions: Conceptualization, R.K. and H.K.-N.; methodology, R.K., A.I., K.S. and H.K.-N. software, R.K.; formal analysis, R.K.; investigation, R.K.; resources, R.K. data curation, H.K.-N.; writing - original draft preparation, R.K. and H.K.-N.; writing—review and editing, R.K. and H.K.-N.; visualization, R.K.; supervision, H.K.-N. All authors have read and agreed to the published version of the manuscript.

Funding: This research was supported by a Ministry of Education, Culture, Sports, Science and Technology (MEXT), Japan scholarship (grant number MEXT 172586).

Data Availability Statement: Not applicable.

Acknowledgments: The authors are grateful to the United Graduate School of Agricultural Sciences, Ehime University, Japan.

Conflicts of Interest: The authors declare no conflict of interest.

\section{References}

1. $\quad$ Rice, E.L. Allelopathy, 2nd ed.; Academic Press: Orlando, FL, USA, 1984; pp. 67-68.

2. Hao, W.Y.; Ren, L.X.; Ran, W.; Shen, Q.R. Allelopathic effects of root exudates from watermelon and rice plants on Fusarium oxysporum f. sp. niveum. Plant Soil 2010, 336, 485-497. [CrossRef] 
3. Chu, C.; Mortimer, P.E.; Wang, H.; Wang, Y.; Liu, X.; Yu, S. Allelopathic effects of Eucalyptus on native and introduced tree species. For. Ecol. Manag. 2014, 323, 79-84. [CrossRef]

4. Macías, F.A.; Marin, D.; Oliveros-Bastidas, A.; Varela, R.M.; Simonet, A.M.; Carrera, C.; Molinillo, J.M. Allelopathy as a new strategy for sustainable ecosystems development. Biol. Sci. Space 2003, 17, 18-23. [CrossRef]

5. Kato-Noguchi, H.; Fushimi, Y.; Shigemori, H. An allelopathic substance in red pine needles (Pinus densiflora). J. Plant Physiol. 2009, 166, 442-446. [CrossRef]

6. Latif, S.; Chiapusio, G.; Weston, L.A. Chapter two-Allelopathy and the role of allelochemicals in plant defence. Adv. Bot. Res 2017, 82, 19-54. [CrossRef]

7. Peres, M.T.L.P.; da Silva Cândido, A.C.; Bonilla, M.B.; Faccenda, O.; Hess, S.C. Phytotoxic potential of Senna occidentalis and Senna obtusifolia. Acta Sci. Biol. Sci. 2010, 32, 305-309. [CrossRef]

8. Da Silva, I.F.; Vieira, E.A. Phytotoxic potential of Senna occidentalis (L.) Link extracts on seed germination and oxidative stress of Ipê seedlings. Plant Biol. 2019, 21, 770-779. [CrossRef]

9. Dayan, F.E.; Cantrell, C.L.; Duke, S.O. Natural products in crop protection. Bioorg. Med. Chem. 2009, 17, 4022-4034. [CrossRef]

10. El-Deek, M.H.; Hess, F.D. Inhibited mitotic entry is the cause of growth inhibition by cinmethylin. Weed Sci. 1986, 34, 684-688. [CrossRef]

11. Grossmann, K.; Hutzler, J.; Tresch, S.; Christiansen, N.; Looser, R.; Ehrhardt, T. On the mode of action of the herbicides cinmethylin and 5-benzyloxymethyl-1, 2-isoxazolines: Putative inhibitors of plant tyrosine aminotransferase. Pest Manag. Sci. 2011, 68, 482-492. [CrossRef]

12. Islam, M.S.; Zaman, F.; Iwasaki, A.; Suenaga, K.; Kato-Noguchi, H. Isolation and identification of three potential phytotoxic compounds from Chrysopogon aciculatus (Retz.) Trin. Acta Physiol. Plant. 2021, 43, 56. [CrossRef]

13. Alsaadawi, I.; Khaliq, A.; Al-Temimi, A.; Matloob, A. Integration of sunflower (Helianthus annuus) residues with a pre-plant herbicide enhances weed suppression in broad bean (Vicia faba). Planta Daninha 2011, 29, 849-859. [CrossRef]

14. Dayan, F.E.; Owens, D.K.; Duke, S.O. Rationale for a natural products approach to herbicide discovery. Pest Manag. Sci. 2012, 68, 519-528. [CrossRef] [PubMed]

15. Poonpaiboonpipat, T.; Krumsri, R.; Kato-Noguchi, H. Allelopathic and herbicidal effects of crude extract from Chromolaena odorata (L.) R.M. King and H. Rob. on Echinochloa crus-galli and Amaranthus viridis. Plants 2021, 10, 1609. [CrossRef] [PubMed]

16. Dayan, F.E.; Romagni, J.G.; Duke, S.O. Investigating the mode of action of natural phytotoxins. J. Chem. Ecol. 2000, 26, 2079-2094. [CrossRef]

17. Lewis, G.P. Tribe Cassieae. In Legumes of the World; Lewis, G.P., Scrhir, B., Mackinder, B., Lock, M., Eds.; Royal Botanic Garden: Kew, UK, 2005; pp. 111-125.

18. Hennebelle, T.; Weniger, B.; Joseph, H.; Sahpaz, S.; Bailleul, F. Senna alata. Fitoterapia 2009, 80, 385-393. [CrossRef]

19. Ibrahim, M.A.; Islam, M.S. Anti-diabetic effects of the acetone fraction of Senna singueana stem bark in a type 2 diabetes rat model. J. Ethnopharmacol. 2014, 153, 392-399. [CrossRef]

20. Torquato, I.H.S.; da Costa, N.C.; Pereira, K.S.; Campos, N.B.; de Oliveira, A.A.; Generino, M.E.M.; Bezerra, J.W.A.; dos Santos, M.A.F.; Sousa, J.D.; Boligon, A.A.; et al. Polyphenolic composition and allelopathic potential of Senna cearensis Afr. fern. (Fabaceae). Res. Soc. Dev. 2020, 9, e577986207. [CrossRef]

21. Monkheang, P.; Sudmoon, R.; Tanee, T.; Noikotr, K.; Bletter, N.; Chaveerach, A. Species diversity, usages, molecular markers and barcode of medicinal Senna species (Fabaceae, Caesalpinioideae) in Thailand. J. Med. Plant Res. 2011, 5, 6173-6181. [CrossRef]

22. Pattarapongdilok, N.; Malichim, P.; Simmee, N.; Sichaem, J. Senna flower extract as an indicator for acid-base titration. Rasayan J. Chem. 2021, 14, 1402-1407. [CrossRef]

23. Surapanthanakorn, S.; Phadoongsombut, N.; Wattanapiromsakul, C.; Reanmongkol, W. In vivo evaluation of analgesic and antipyretic activities of piceatannol-rich extract from Senna garrettiana heartwood. Songklanakarin J. Sci. Technol. 2016, 39, 589-599.

24. Sakunpak, A.; Saingam, W. Screening and compound isolation from selected Thai herbal medicine for anti-hyaluronidase and anti-elastase activities. In Proceedings of the RSU International Research Conference (2020), Bangkok, Thailand, 1 May 2020; pp. 305-311.

25. Dave, H.; Ledwani, L. A review on anthraquinones isolated from Cassia species and their applications. Indian J. Nat. Prod. Resour. 2012, 3, 291-319.

26. Piotrowska, H.; Kucinska, M.; Murias, M. Biological activity of piceatannol: Leaving the shadow of resveratrol. Mutat. Res. Rev. Mutat. Res. 2012, 750, 60-82. [CrossRef] [PubMed]

27. Surapanthanakorn, S.; Wattanapiromsakul, C.; Reanmongkol, W. Assessment of the anti-inflammatory activity of piceatannol-rich extract from Senna garrettiana heartwood. Chiang Mai J. Sci. 2018, 45, 2691-2702.

28. Baez, D.A.; Zepeda Vallejo, L.G.; Jimenez-Estrada, M. Phytochemical studies on Senna skinneri and Senna wislizeni. Nat. Prod. Lett. 1999, 13, 223-228. [CrossRef]

29. Ganeshpurkar, A.; Saluja, A.K. The pharmacological potential of rutin. Saudi Pharm. J. 2017, 25, 149-164. [CrossRef]

30. Franco, D.M.; Silva, E.M.; Saldanha, L.L.; Adachi, S.A.; Schley, T.R.; Rodrigues, T.M.; Dokkedal, A.L.; Nogueira, F.T.S.; Rolim de Almeida, L.F. Flavonoids modify root growth and modulate expression of SHORT-ROOT and HD-ZIP III. J. Plant Physiol. 2015, 188, 89-95. [CrossRef]

31. Bari, I.N.; Kato-Noguchi, H.; Iwasaki, A.; Suenaga, K. Allelopathic potency and an active substance from Anredera cordifolia (Tenore) Steenis. Plants 2019, 8, 134. [CrossRef] 
32. Boonmee, S.; Suwitchayanon, P.; Krumsri, R.; Kato-Noguchi, H. Investigation of the allelopathic potential of Nephrolepis cordifolia (L.) C. Presl against dicotyledonous and monocotyledonous plant species. Environ. Control. Biol. 2020, 58, 71-78. [CrossRef]

33. Krumsri, R.; Iwasaki, A.; Suenaga, K.; Kato-Noguchi, H. Assessment of allelopathic potential of Dalbergia cochinchinensis Pierre and its growth inhibitory substance. Emir. J. Food Agric. 2020, 32, 513-521. [CrossRef]

34. Motmainna, M.; Juraimi, A.S.; Uddin, M.; Asib, N.B.; Islam, A.K.M.; Ahmad-Hamdani, M.S.; Hasan, M. Phytochemical constituents and allelopathic potential of Parthenium hysterophorus L. in comparison to commercial herbicides to control weeds. Plants 2021, 10, 1445. [CrossRef]

35. Rob, M.; Iwasaki, A.; Suzuki, R.; Suenaga, K.; Kato-Noguchi, H. Garcienone, a novel compound involved in allelopathic activity of Garcinia Xanthochymus hook. Plants 2019, 8, 301. [CrossRef]

36. Krumsri, R.; Kato-Noguchi, H.; Poonpaiboonpipat, T. Allelopathic effect of Sphenoclea zeylanica Gaertn. on rice (Oryza sativa L.) germination and seedling growth. Aust. J. Crop Sci. 2020, 14, 1450-1455. [CrossRef]

37. Kyaw, E.H.; Kato-Noguchi, H. Assessment of allelopathic activity of Tradescantia spathacea Sw. for weed control. Biol. Futur. 2021, 1-7. [CrossRef]

38. Sasidharan, S.; Chen, Y.; Saravanan, D.; Sundram, K.; Latha, L. Extraction, isolation and characterization of bioactive compounds from plants' extracts. Afr. J. Tradit. Complement. Altern. Med. 2011, 8, 1-10. [CrossRef] [PubMed]

39. Silva, C.B.; Candido, A.C.S.; Simionatto, E.; Faccenda, O.; Scalon, S.D.P.Q.; Peres, M.T.L.P. Allelopathic and antioxidant activity and total phenolic contents of Hydrocotyle bonariensis Lam. (Araliaceae)/Atividade alelopatica, antioxidante e teor de fenois totais de Hydrocotyle bonariensis Lam. (Araliaceae). Acta Sci. Technol. 2010, 32, 413-421.

40. Pereira, J.C.; Paulino, C.; Endres, L.; Santana, A.E.G.; Pereira, F.R.S.; Souza, R.C. Allelopathic potential of ethanolic extract and phytochemical analysis of Paspalum maritimum Trind. Planta Daninha 2019, 37, 1-12. [CrossRef]

41. Blum, U. Allelopathic interactions involving phenolic acids. J. Nematol. 1996, 28, 259-267. [PubMed]

42. Mirmostafaee, S.; Azizi, M.; Fujii, Y. Study of allelopathic interaction of essential oils from medicinal and aromatic plants on seed germination and seedling growth of lettuce. Agronomy 2020, 10, 163. [CrossRef]

43. Lee, S.Y.; Choi, S.U.; Lee, J.H.; Lee, D.U.; Lee, K.R. A new phenylpropane glycoside from the rhizome of Sparganium stoloniferum. Arch. Pharm. Res. 2010, 33, 515-521. [CrossRef]

44. Kim, S.J.; Kim, M.C.; Um, J.Y.; Hong, S.H. The beneficial effect of vanillic acid on ulcerative colitis. Molecules 2010, 15, 7208-7217. [CrossRef]

45. Anantharaju, P.G.; Gowda, P.C.; Vimalambike, M.G.; Madhunapantula, S.V. An overview on the role of dietary phenolics for the treatment of cancers. J. Nutr. 2016, 15, 1-16. [CrossRef] [PubMed]

46. Sampietro, D.A.; Vattuone, M.A.; Isla, M.I. Plant growth inhibitors isolated from sugarcane (Saccharum officinarum) straw. J. Plant Physiol. 2006, 63, 837-846. [CrossRef]

47. Hussain, F.; Ghulam, S.; Sher, Z.; Ahmad, B. Allelopathy by Lantana camara. Pak. J. Bot. 2011, 43, $2373-2378$.

48. Gurmani, A.R.; Khan, S.U.; Mehmood, T.; Ahmed, W.; Rafique, M. Exploring the allelopathic potential of plant extracts for weed suppression and productivity in wheat (Triticum aestivum L.). Gesunde Pflanz. 2021, 73, 29-37. [CrossRef]

49. Amin, H.P.; Czank, C.; Raheem, S.; Zhang, Q.; Botting, N.P.; Cassidy, A.; Kay, C.D. Anthocyanins and their physiologically relevant metabolites alter the expression of IL-6 and VCAM-1 in CD40L and oxidized LDL challenged vascular endothelial cells. Mol. Nutr. Food Res. 2015, 59, 1095-1106. [CrossRef]

50. Hu, R.; Wu, S.; Li, B.; Tan, J.; Yan, J.; Wang, Y.; Tanga, Z.; Liub, M.; Fua, C.; Zhangc, H.; et al. Dietary ferulic acid and vanillic acid on inflammation, gut barrier function and growth performance in lipopolysaccharide-challenged piglets. Anim. Nutr. 2021 [CrossRef] [PubMed]

51. Naz, S.; Ahmad, S.; Ajaz Rasool, S.; Asad Sayeed, S.; Siddiqi, R. Antibacterial activity directed isolation of compounds from Onosma hispidum. Microbiol. Res. 2006, 161, 43-48. [CrossRef] [PubMed]

52. Aljović, I.; Gojak-Salimović, S. Evaluation of the antioxidant activity of ferulic, homovanillic and vanillic acids using the Briggs-Rauscher oscillating reaction method. Glas. Hem. Tehnol. Bosne Herceg. 2017, 49, 35-38.

53. Li, Q.; Chang, X.; Guo, R.; Wang, Q.; Guo, X. Dynamic effects of fermentation on phytochemical composition and antioxidant properties of wampee (Clausena lansium (Lour.) Skeel) leaves. Food Sci. Nutr. 2019, 7, 76-85. [CrossRef]

54. Inderjit; Nilsen, E.T. Bioassays and field studies for allelopathy in terrestrial plants: Progress and problems. Crit. Rev. Plant Sci. 2003, 22, 221-238. [CrossRef]

55. Hussain, M.I.; El-Sheikh, M.A.; Reigosa, M.J. Allelopathic potential of aqueous extract from Acacia melanoxylon R. Br. on Lactuca sativa. Plants 2020, 9, 1228. [CrossRef]

56. Einhellig, F.A.; Rasmussen, J.A. Effects of three phenolic acids on chlorophyll content and growth of soybean and grain sorghum seedlings. J. Chem. Ecol. 1979, 5, 815-824. [CrossRef]

57. Chung, I.M.; Kim, K.H.; Ahn, J.K.; Chun, S.C.; Kim, C.S.; Kim, J.T.; Kim, S.H. Screening of allelochemicals on barnyardgrass (Echinochloa crus-galli) and identification of potentially allelopathic compounds from rice (Oryza sativa) variety hull extracts. $J$. Crop Prot. 2002, 21, 913-920. [CrossRef]

58. Nishida, N.; Tamotsu, S.; Nagata, N.; Saito, C.; Sakai, A. Allelopathic effects of volatile monoterpenoids produced by Salvia leucophylla: Inhibition of cell proliferation and DNA synthesis in the root apical meristem of Brassica campestris seedlings. J. Chem. Ecol. 2005, 31, 1187-1203. [CrossRef] [PubMed] 
59. Wang, Y.; Liang, J.; Luan, G.; Zhang, S.; Zhuoma, Y.; Xie, J.; Zhou, W. Quantitative analyses of nine phenolic compounds and their antioxidant activities from thirty-seven varieties of raspberry grown in the qinghai-tibetan plateau region. Molecules 2019, 24, 3932. [CrossRef]

60. Parvin, K.; Nahar, K.; Hasanuzzaman, M.; Bhuyan, M.B.; Mohsin, S.M.; Fujita, M. Exogenous vanillic acid enhances salt tolerance of tomato: Insight into plant antioxidant defense and glyoxalase systems. Plant Physiol. Biochem. 2020, 150, 109-120. [CrossRef] [PubMed]

61. Poonpaiboonpipat, T.; Pangnakorn, U.; Suvunnamek, U.; Teerarak, M.; Charoenying, P.; Laosinwattana, C. Phytotoxic effects of essential oil from Cymbopogon citratus and its physiological mechanisms on barnyardgrass (Echinochloa crus-galli). Ind. Crops Prod. 2013, 41, 403-407. [CrossRef]

62. Hayat, S.; Ahmad, H.; Ali, M.; Ren, K.; Cheng, Z. Aqueous garlic extract stimulates growth and antioxidant enzymes activity of tomato (Solanum lycopersicum). Sci. Hortic. 2018, 240, 139-146. [CrossRef]

63. Mecina, G.F.; Chia, M.A.; Cordeiro-Araújo, M.K.; do Carmo Bittencourt-Oliveira, M.; Varela, R.M.; Torres, A.; Molinillo, J.M.G.; Macías, F.A.; da Silva, R.M.G. Effect of flavonoids isolated from Tridax procumbens on the growth and toxin production of Microcystis aeruginos. Aquat. Toxicol. 2019, 211, 81-91. [CrossRef] [PubMed]

64. Talukdar, D. Allelopathic effects of Lantana camara L. on Lathyrus sativus L.: Oxidative imbalance and cytogenetic consequences. Allelopathy J. 2013, 31, 71-90.

65. Rial, C.; García, B.F.; Varela, R.M.; Torres, A.; Molinillo, J.M.; Macías, F.A. The joint action of sesquiterpene lactones from leaves as an explanation for the activity of Cynara cardunculus. J. Agric. Food Chem. 2016, 64, 6416-6424. [CrossRef] [PubMed]

66. Tena, C.; Santiago, A.D.R.; Osuna, D.; Sosa, T. Phytotoxic activity of p-cresol, 2-phenylethanol and 3-phenyl-1-propanol, phenolic compounds present in Cistus ladanifer L. Plants 2021, 10, 1136. [CrossRef] [PubMed]

67. Inderjit; Streibig, J.C.; Olofsdotter, M. Joint action of phenolic acid mixtures and its significance in allelopathy research. Physiol. Plant. 2002, 114, 422-428. [CrossRef] [PubMed]

68. Jia, C.; Kudsk, P.; Mathiassen, S.K. Joint action of benzoxazinone derivatives and phenolic acids. J. Agric. Food Chem. 2006, 54, 1049-1057. [CrossRef] [PubMed] 